\title{
Using Harvested Rainwater for Potato Production under Rainfed Condition
}

\author{
Susanta Sarmah Pathak ${ }^{*}$, Er. Rajat Paul and Nilakshi Dutta \\ Department of Agril. Statistics, Department of Agril. Engineering, \\ $B N$ College of Agriculture, AAU, Biswanath, Assam, India \\ *Corresponding author
}

\section{Keywords}

Rainwater harvesting, vermicompost, potato, yield

\section{Article Info}

Accepted:

15 May 2018

Available Online:

10 June 2018

\section{A B S T R A C T}

A field experiment was conducted at the experimental field, All India Coordinated Research Project on Dryland Agriculture, Biswanath Chariali centre, Biswanath College of Agriculture, Assam Agricultural University, Biswanath Chariali during the Rabi season of 2013-14 to study the "Efficiency of harvested rainwater on potato under rainfed condition". The treatment comprised of four irrigation levels in the main plot viz. No irrigation, one irrigation at 25 days after planting, two irrigation at 25 and 60 DAP, \& three irrigation at 25,60 and $80 \mathrm{DAP}$, in combination with two sub-plot of organic viz. no organic and with organic (i.e. vermicompost @ $2 \mathrm{t} \mathrm{ha}^{-1}$ ) treatment. These treatments were evaluated under split plot design with three replications. The finding revealed that harvested rainwater applied three times at $25,60 \& 80$ DAP recorded the highest total tuber yield $\left(22.69 \mathrm{t} \mathrm{ha}^{-1}\right)$ over other irrigation levels. Application of organic in terms of vermicompost @ $2 \mathrm{t} \mathrm{ha}^{-1}$ significantly increased the tuber yield of potato $\left(17.55 \mathrm{t} \mathrm{ha}^{-1}\right)$ over non-organic treatment $\left(15.87 \mathrm{t} \mathrm{ha}^{-1}\right)$ by $10.59 \%$. Organic recorded the highest water use efficiency $\left(188.85 \mathrm{~kg} \mathrm{ha}^{-1} \mathrm{~mm}^{-1}\right)$, which was 16.64 per cent higher over non-organic treatment. Though, irrigation at 25,60 and 80 DAP with vermicompost gave the higher yield $\left(23.39 \mathrm{tha}^{-1}\right)$, yet the highest $\mathrm{B}: \mathrm{C}$ ratio $(2.17)$ was recorded in the treatment receiving harvested rainwater applied at 25,60 and 80 days after planting under no organic treatment. Thus, it may be inferred that with a rainwater harvesting volume of 270.11 ha $\mathrm{mm}$, an area of one hectare potato crop can be irrigated applying $233.14 \mathrm{~mm}$ irrigation in furrow system at 25, 60 and 80 days after planting with recommended dose of organic and inorganic fertililizers for obtaining economically viable tuber yield of potato under prevailing situations.

\section{Introduction}

Potato (Solanum tuberosum L.) is one of the most important and extensively cultivated rainfed vegetable crop of Assam and ranks eighth in the total potato production in the country with productivity of $7.12 \mathrm{t} \mathrm{ha}^{-1}$ and fourth in terms of acreage under individual crop in the state (Saikia, 2011). The potato growing season is characterized by cool-dry climate with very low and earlier rainfall necessitating irrigation for higher potato production. Most of the farmers (83\%) being of small and marginal category cannot effort for costly irrigation structure, recently attempts are being made to explore the possibilities of utilizing harvested rainwater on productivity of potato and to evaluate the 
integrated effects of harvested rainwater and organic manure on potato. Standardization of tank size with water requirement for optimum potato production, is an important consideration for successful introduction of rainwater harvesting tank with suitable size for production of potato. Rainwater harvesting is an useful tool to mitigate water stress and dry spell during the cropping season. As Assam is in high rainfall zone of India, stored harvested rainwater is used for supplemental irrigation to minimize water stress on vegetable crops particularly during high soil moisture deficit period (Ngigi, 2003). Use of organic manure like, vermicompost helps in increasing microbial organisms and nutrient status of soil due to long lasting residual effects. It also modulates structure of the existing soil, increases water retention capacity (Ferress et al., 2006). The small farm reservoir increased the intensity of vegetable cultivation, which resulted in increasing the farmer's income from marginal land by as much as $37.5 \%$ (Hafif and Murni, 2012). The present experiment was conducted with a view to examine critically and to achieve maximum yield under the different irrigation level and organic condition.

\section{Materials and Methods}

A field experiment was conducted at Instructional cum Research Farm of All India Coordinated Research Project for Dryland Agriculture, Biswanath College of Agriculture, Assam Agricultural University, Biswanath Chariali $\left(26^{\circ} 43^{\prime} 32^{\prime \prime} \mathrm{N}\right.$ and $93^{\circ}$ $08^{\prime} 01^{\prime \prime}$ E) during Rabi season (October, 2013 to February, 2014). The topography has average slope of $0-1$ percent. Soil texture was sandy loam and infiltration rate was considerably high $(3.5 \mathrm{~cm} / \mathrm{h})$ with low water holding capacity $(16.2 \%)$. The field capacity, permanent wilting point and bulk density of the soil was 21.85 percent, 5.65 percent and $1.21 \mathrm{~g} \mathrm{cc}^{-1}$, respectively. The soil was acidic with a pH of 5.1 and EC of 0.001-0.026 dSm$1_{\text {and }}$ medium in available Organic carbon $(0.69 \%)$ and available $\mathrm{P}_{2} \mathrm{O}_{5}\left(28.26 \mathrm{~kg} \mathrm{ha}^{-1}\right)$; and low in available $\mathrm{N}\left(235.10 \mathrm{~kg} \mathrm{ha}^{-1}\right)$ and $\mathrm{K}_{2} \mathrm{O}$ (109.30 $\mathrm{kg} \mathrm{ha}^{-1}$ ). During 2013-14, the station received annual rainfall of $1620.8 \mathrm{~mm}$, while during pre-monsoon, monsoon, postmonsoon and winter period the average rainfall was $435.9 \mathrm{~mm}$ (27\% of total rainfall), $1063.1 \mathrm{~mm}$ ( $66 \%$ of total rainfall), $98.8 \mathrm{~mm}$ (6\% of total rainfall) and $23.0 \mathrm{~mm}$ (1\% of total rainfall), respectively. All the districts of North Bank Plain Zone of Assam experienced drought like situation during monsoon season, 2013; which was due to uneven distribution of rainfall pattern. In general, extreme temperature variation is not encountered in this zone. A total rainfall of $49.20 \mathrm{~mm}$ was received in 7 rainy days during the cropping period (15th October, 2013 to $16^{\text {th }}$ February, 2014).

The experiment comprising of 8 treatment combinations replicated 3 times was laid out in split-plot design with 4 level of irrigation allocated to main plots and 2 organic practices to sub-plots. The 4 irrigation practices were no irrigation (rainfed) $\left(\mathrm{IR}_{0}\right)$, one irrigation at 25 days after planting (DAP) $\left(\mathrm{IR}_{1}\right)$, two irrigation at 25 and $60 \mathrm{DAP}\left(\mathrm{IR}_{2}\right)$, three irrigation at 25 , 60 and $80 \mathrm{DAP}\left(\mathrm{IR}_{3}\right)$. The organic practices were without vermicompost $\left(\mathrm{OC}_{0}\right)$ and with organics- with application of vermicompost @ $10 \mathrm{t} \mathrm{ha}^{-1}\left(\mathrm{OC}_{1}\right)$. The potato variety 'Kufri Jyoti' was planted on $04^{\text {th }}$ November, 2013 and harvested on $16^{\text {th }}$ February, 2014.

A cement lined concrete pond with dimension of top $21 \mathrm{~m} \mathrm{X} 17 \mathrm{~m}$; bottom $11 \mathrm{~m} \mathrm{X} 6 \mathrm{~m}$ and height of $2.5 \mathrm{~m}$; was constructed and rainwater was harvested from $1^{\text {st }}$ January, 2013 onwards, which was utilized for irrigation purpose for potato production in Rabi season. The rainwater stored in the farm pond and duration of availability of water in the pond was recorded at standard meteorological week. The 
recommended package of practices and the need-based cultural operations and plantprotection measures were followed. Economics for each treatment was worked out based on market rate of inputs and outputs. The important growth and yield attributes were recorded.

\section{Results and Discussion}

\section{Rainwater harvest potential of farm pond}

Storage volume of rainwater in the cementlined tank was increased with precipitation and the maximum rainwater volume of 29.37 ha $\mathrm{mm}$ was recorded on $19^{\text {th }}$ August, 2013 (33 ${ }^{\text {rd }}$ SMW) (Fig. 4.1 and Appendix III). The surface area was the catchment area $(21 \mathrm{~m}$ $\mathrm{x} 17 \mathrm{~m}$ ) of the tank. Again, with the cessation of monsoon season the volume of harvested rainwater declined and a volume of 25.34 ha $\mathrm{mm}$ was recorded on $25^{\text {th }}$ November, 2013 $\left(47^{\text {th }}\right.$ SMW). This quantity of harvested rainwater could be used for irrigation purpose for growing of potato crop, as first irrigation at 25 days after planting (DAP) was applied on $29^{\text {th }}$ November, 2013 (Tab. 3.6 and Appendix III).

The storage quantity of harvested rainwater in the cement lined tank increased with precipitation during pre-monsoon (MarchMay) and monsoon season (June-September). The precipitation in monsoon season was 65.63 percent of total rainfall (Table 4.1).

The observed decrease in storage quantity of harvested rainwater from $39^{\text {th }} \mathrm{SMW}$ onwards (Fig. 4.1) might be due to evaporation from tank as well as use of harvested rainwater from the tank for irrigation in potato crop. Therefore proper evaporation control measure may be developed to improve tank storability of harvested rainwater. Reddy (2006) also reported that the storability of harvested rainwater decreased because of evaporation.

\section{Rainwater use-efficiency $\left(\mathrm{kg} \mathrm{ha}^{-1} \mathrm{~mm}^{-1}\right)$}

\section{Effect of harvested rainwater (IR)}

Rainwater use efficiency due to application of different levels of irrigation through harvested rainwater recorded significant effect. No irrigation treatment i.e. rainfed condition $\left(\mathrm{IR}_{0}\right)$ exhibited the highest rainwater use-efficiency $\left(159.53 \mathrm{~kg} \mathrm{ha}^{-1} \mathrm{~mm}^{-1}\right)$ followed by harvested rainwater applied at $25 \mathrm{DAP}\left(\mathrm{IR}_{1}\right)(101.48 \mathrm{~kg}$ $\left.\mathrm{ha}^{-1} \mathrm{~mm}^{-1}\right)$. On the other hand harvested rainwater applied at 25, 60 and $80 \mathrm{DAP}\left(\mathrm{IR}_{3}\right)$ recorded the lowest rainwater use-efficiency $\left(77.45 \mathrm{~kg} \mathrm{ha}^{-1} \mathrm{~mm}^{-1}\right)$. It was revealed from the analysed data (Table 4.4) that rainfed condition $\left(\mathrm{IR}_{0}\right)$ resulted in 105.98 per cent higher rainwater use efficiency than harvested rainwater applied at 25, 60 and $80 \mathrm{DAP}\left(\mathrm{IR}_{3}\right)$ (Table 4.4).

\section{Effect of organic (OC)}

Application of organic $\left(\mathrm{OC}_{1}\right)$ significantly increased the rainwater use efficiency over non-organic $\left(\mathrm{OC}_{0}\right)$ condition. The higher rainwater use efficiency of $115.93 \mathrm{~kg} \mathrm{ha}^{-1} \mathrm{~mm}^{-}$ 1 was recorded under organic $\left(\mathrm{OC}_{1}\right)$ as compared to non-organic $\left(\mathrm{OC}_{0}\right)\left(97.54 \mathrm{~kg} \mathrm{ha}^{-1}\right.$ $\left.\mathrm{mm}^{-1}\right)$. The use of organic $\left(\mathrm{OC}_{1}\right)$ increased the rainwater use efficiency by 18.85 per cent over non-organic $\left(\mathrm{OC}_{0}\right)$ plots (Table 4.4).

\section{Interaction effect of harvested rainwater and organic $(\mathrm{IR} \times \mathrm{OC})$}

The interaction between harvested rainwater and organic was found to have significant effect on rainwater use efficiency. Rainfed condition $\left(\mathrm{IR}_{0}\right)$ under organic $\left(\mathrm{OC}_{1}\right)$ recorded the highest rainwater use efficiency (179.62 $\mathrm{kg} \mathrm{ha}^{-1} \mathrm{~mm}^{-1}$ ). On the other hand, harvested rainwater applied at 25,60 and $80 \mathrm{DAP}\left(\mathrm{IR}_{3}\right)$ under non-organic $\left(\mathrm{OC}_{0}\right)$ recorded lowest water use efficiency $\left(75.19 \mathrm{~kg} \mathrm{ha}^{-1} \mathrm{~mm}^{-1}\right)$ (Table 4.5). 
Table.1 Seasonal rainfall pattern of the station

\begin{tabular}{|c|c|c|c|}
\hline Season(month) (2013-14) & $\begin{array}{l}\text { Normal (1972- } \\
\text { 2012) (mm) }\end{array}$ & $\begin{array}{l}\text { Actual }(2013- \\
\text { 14) }(\mathrm{mm})\end{array}$ & $\begin{array}{l}\text { Actual \% rainfall } \\
( \pm) \text { over Normal }\end{array}$ \\
\hline Pre-monsoon (March-May) & $\begin{array}{c}486.5 \\
(24.57)\end{array}$ & $\begin{array}{c}435.9 \\
(26.89)\end{array}$ & -10.40 \\
\hline Monsoon (June-September) & $\begin{array}{l}1279.9 \\
(64.64)\end{array}$ & $\begin{array}{l}1063.1 \\
(65.59)\end{array}$ & -16.94 \\
\hline $\begin{array}{l}\text { Post-monsoon (October- } \\
\text { November) }\end{array}$ & $\begin{array}{l}150.3 \\
(7.59)\end{array}$ & $\begin{array}{c}98.8 \\
(6.10)\end{array}$ & -34.26 \\
\hline Winter (December-February) & $\begin{array}{c}63.3 \\
(3.19)\end{array}$ & $\begin{array}{c}23.0 \\
(1.42)\end{array}$ & -63.67 \\
\hline Total & 1980.0 & 1620.8 & -18.14 \\
\hline
\end{tabular}

(Figures in parentheses indicate percentage of rainfall over total annual rainfall)

Table.2 Harvested rainwater requirement (mm) for irrigation

\begin{tabular}{|c|c|c|c|c|c|}
\hline & \multicolumn{3}{|c|}{ Moisture deficit (cm) } & & \\
\hline Treatment combination & 25 DAP & 60 DAP & 80 DAP & $\mathrm{NIR}, \mathrm{mm}$ & GIR, mm \\
\hline $\mathrm{IR}_{1} \mathrm{OC}_{0}$ & 5.48 & 0.00 & 0.00 & 54.8 & 78.29 \\
\hline $\mathrm{IR}_{1} \mathrm{OC}_{1}$ & 5.27 & 0.00 & 0.00 & 52.7 & 75.29 \\
\hline $\mathrm{IR}_{2} \mathrm{OC}_{0}$ & 5.36 & 5.59 & 0.00 & 109.4 & 156.29 \\
\hline $\mathrm{IR}_{2} \mathrm{OC}_{1}$ & 5.39 & 5.69 & 0.00 & 110.8 & 158.29 \\
\hline $\mathrm{IR}_{3} \mathrm{OC}_{0}$ & 5.30 & 5.69 & 5.33 & 163.2 & 233.14 \\
\hline $\mathrm{IR}_{3} \mathrm{OC}_{1}$ & 5.42 & 5.64 & 5.31 & 163.7 & 233.86 \\
\hline
\end{tabular}

NIR= Net Irrigation requirement, GIR= Gross Irrigation Requirement (DAP = days after planting)

Table.3 Irrigation potential of the rainwater harvesting tank

\begin{tabular}{|c|c|c|c|c|}
\hline Treatment & $\begin{array}{c}\text { Gross harvested } \\
\text { rainwater } \\
\text { requirement }(\mathbf{m m})\end{array}$ & $\begin{array}{c}\text { Total } \\
\text { Rainwater } \\
\text { used }(\mathbf{m m})\end{array}$ & $\begin{array}{c}\text { *Irrigation } \\
\text { potential (ha) }\end{array}$ & $\begin{array}{c}* * \text { Harvesting tank } \\
\text { volume for } \mathbf{1} \text { ha land } \\
\text { (ha } \mathbf{~ m m} \text { ) }\end{array}$ \\
\hline $\mathbf{I R}_{\mathbf{1}} \mathbf{O} \mathbf{C}_{\mathbf{0}}$ & 78.29 & 146.49 & 0.324 & 90.71 \\
\hline $\mathbf{I R}_{\mathbf{1}} \mathbf{O} \mathbf{C}_{\mathbf{1}}$ & 75.29 & 143.49 & 0.337 & 87.23 \\
\hline $\mathbf{I R}_{\mathbf{2}} \mathbf{O} \mathbf{C}_{\mathbf{0}}$ & 156.29 & 224.49 & 0.162 & 181.07 \\
\hline $\mathbf{I R}_{\mathbf{2}} \mathbf{O} \mathbf{C}_{\mathbf{1}}$ & 158.29 & 226.49 & 0.160 & 183.39 \\
\hline $\mathbf{I R}_{\mathbf{3}} \mathbf{O} \mathbf{C}_{\mathbf{0}}$ & 233.14 & 301.34 & 0.109 & 270.11 \\
\hline $\mathbf{I R}_{\mathbf{3}} \mathbf{O} \mathbf{C}_{\mathbf{1}}$ & 233.86 & 302.06 & 0.108 & 270.95 \\
\hline
\end{tabular}

(*Harvested rainwater volume of the tank was $25.34 \mathrm{ha} \mathrm{mm}$ at $47^{\text {th }} \mathrm{SMW}$ on $25^{\text {th }}$ November, 2013 and a total rainfall of $68.2 \mathrm{~mm}$ was received by all the treatments)

(**The maximum volume of harvested rainwater was 29.37 ha $\mathrm{mm}$ at $33^{\text {rd }} \mathrm{SMW}$ on $19^{\text {th }}$ August, 2013$) \#\left(1 \mathrm{ha} \mathrm{mm}=10 \mathrm{~m}^{3}\right)$

The per cent increase in rainwater use efficiency under $\mathrm{IR}_{0} \mathrm{OC}_{1}$ was 138.88 per cent over $\mathrm{IR}_{3} \mathrm{OC}_{0}$. Among the different treatments the highest water use-efficiency $(159.53 \mathrm{~kg}$ $\mathrm{ha}^{-1} \mathrm{~mm}^{-1}$ ) was recorded under rainfed condition (Table 4.4). While, the lowest water use efficiency $\left(77.45 \mathrm{~kg} \mathrm{ha}^{-1} \mathrm{~mm}^{-1}\right)$ was found in $\mathrm{IR}_{3}$. 
The highest water use efficiency observed in $\mathrm{IR}_{0}$ was not because of higher dry matter production but because of efficient utilization of rainwater. On the other hand dry matter production increased with increasing the number of irrigation.

However, it failed to result in higher water use efficiency indicating low utilization of irrigated water for dry-matter production rather there might be luxury consumption of water. During the present study, the use of vermicompost significantly increased water use-efficiency of potato crop as compared to crops grown without vermicompost.

Application of vermicompost might have helped in enhancing the root growth, which can extract more soil moisture and thereby increased dry matter production of plant that finally led to 18.85 per cent higher water use efficiency.

The present study findings were in close conformity with the findings of many earlier workers. Singh et al., (1973) reported $265 \mathrm{~kg}$ $\mathrm{ha}^{-1} \mathrm{~mm}^{-1}$ water use efficiency of potato grown with surface irrigation. Similarly Panigrahi et al., (2001) and Yuan et al., (2003) also studied the water use efficiency of potato under different irrigation schedule and reported higher water use efficiency with drip irrigation compared to furrow irrigation.

\section{Acknowledgement}

Authors are grateful to the Assoc Dean, BNCA for providing the necessary facility to carry out the research.

\section{References}

Ferreras, L.; Gomez, E.; Toresani, S.; Firpo, I. and Ro-tondo, R. (2006). Effect of organic amendments on some physical, chemical and biological properties in a horticultural soil, Bioresource Technology. 97: 635-640.

Hafif, B. and Murni, A.M. (2012). Small Farm Reservoir as a Supplemental Irrigation Source for Crops Planted on Marginal Land. Agrivita, Journal of Agricultural Science. 34 (1): 54-67.

Ngigi, S.N. (2003). What is the Limit of Upscaling Rainwater Harvesting in a River Basin? Physics and Chemistry of the earth. 28: 943-956.

Panigrahi, B.; Panda, B.N. and Raghuwansi, N.S. (2001). Potato water use and yield under furrow irrigation. Irrig. Sci. 20: $155-$

Reddy, Y.A. (2006). National Seminar on Rainwater Harvesting and Water Management, 11-12 Nov, 2006, Nagpur, pp 70-77.

Saikia, M., (2011). Effect of irrigation and mulching on growth, yield and water use efficiency of potato in Assam, Potato J. 38 (1): 81-83.

Singh, K.; Kumar, V. and Pandita, M.L. (1973). Influence of sprinkler and surface irrigation under different levels of nitrogen on growth, yield and quality of potato. Haryana, J. Hort. Sci. 2: 101111.

\section{How to cite this article:}

Susanta Sarmah Pathak, Er. Rajat Paul and Nilakshi Dutta. 2018. Using Harvested Rainwater for Potato Production under Rainfed Condition. Int.J.Curr.Microbiol.App.Sci. 7(06): 13311335. doi: https://doi.org/10.20546/ijcmas.2018.706.156 